\title{
Dealing with Snakes in Florida's Residential Areas - Identifying Commonly Encountered Snakes ${ }^{1}$
}

\section{Steve A. Johnson and Monica E. McGarrity ${ }^{2}$}

Florida's native snake species play important roles in the environment, serving as prey for many native birds and helping to regulate amphibian and rodent populations. Considering the fact that rodents worldwide help to spread 35 known human diseases, we would be well-advised to learn to respect and appreciate snakes for the role they play in our environment. Unfortunately, many snakes are now threatened by habitat loss caused by development of natural habitats to meet the needs of Florida's growing human population. Additionally, large numbers of snakes are killed each year as a result of road mortality and persecution by humans. In the U.S., humans kill thousands of snakes each year, yet only 5-6 people die each year of venomous snakebites. In order for snakes and people to safely coexist, it is important that Floridians learn to identify, understand, and respect snakes.

In residential areas where human-snake encounters are likely to occur, we recommend a three-part proactive approach for coexisting safely with snakes. This document provides information on the first step of this proactive approach - learning to identify Florida's commonly encountered non-venomous and venomous snakes. Please note that, in keeping with the "leave it be" attitude that we advocate, we recommend that you avoid handling snakes if at all possible and NEVER attempt to handle a snake with your bare hands or attempt to handle ANY venomous snake - that is a task best left to professionals.

\section{NON-VENOMOUS SNAKES}

Florida is home to 44 species of native snakes, only six of which are venomous. The 13 species described here are commonly encountered snakes that may be found in yards, golf courses, parks, retention ponds, or even in garages and houses. There are certainly other species of snakes that are found in residential areas, but those listed here are the ones most frequently encountered. For each species, we provide information about how to identify it, what it eats, and where it is commonly found in residential settings, as well as insights on behavior and how to deal with each species safely.

1. This document is WEC 220, the second in a 4-part series entitled "Dealing with Snakes in Florida's Residential Areas", of the Department of Wildlife Ecology and Conservation, University of Florida / IFAS. First published July 2007. Accompanying documents by Dr. Johnson related to dealing with snakes in a variety of settings are available through the University of Florida/EDIS at http://edis.ifas.ufl.edu/TOPIC_A23708620. A free PowerPoint presentation (with speaking notes) on the topic of venomous snake safety is available upon request from Steve A. Johnson by email - tadpole@ufl.edu.

2. Steve A. Johnson - Department of Wildlife Ecology and Conservation and Gulf Coast Research and Education Center, University of Florida IFAS/Plant City Campus, 1200 North Park Road, Plant City, FL 33563

Monica E. McGarrity - Gulf Coast Research and Education Center, University of Florida IFAS/Plant City Campus, Plant City, FL

The Institute of Food and Agricultural Sciences (IFAS) is an Equal Opportunity Institution authorized to provide research, educational information and other services only to individuals and institutions that function with non-discrimination with respect to race, creed, color, religion, age, disability, sex, sexual orientation, marital status, national origin, political opinions or affiliations. U.S. Department of Agriculture, Cooperative Extension Service, University of Florida, IFAS, Florida A. \& M. University Cooperative Extension Program, and Boards of County Commissioners Cooperating. Larry Arrington, Dean 


\section{Southern Black Racer}

The Southern Black Racer (Coluber constrictor), also known as the Eastern Racer, is the "black snake" most commonly found in urban and natural areas throughout all of Florida (Figure 1). These long, slender snakes can grow to 4-5 feet in length, and have smooth gray/black scales on their backs and bellies and white chins and throats.

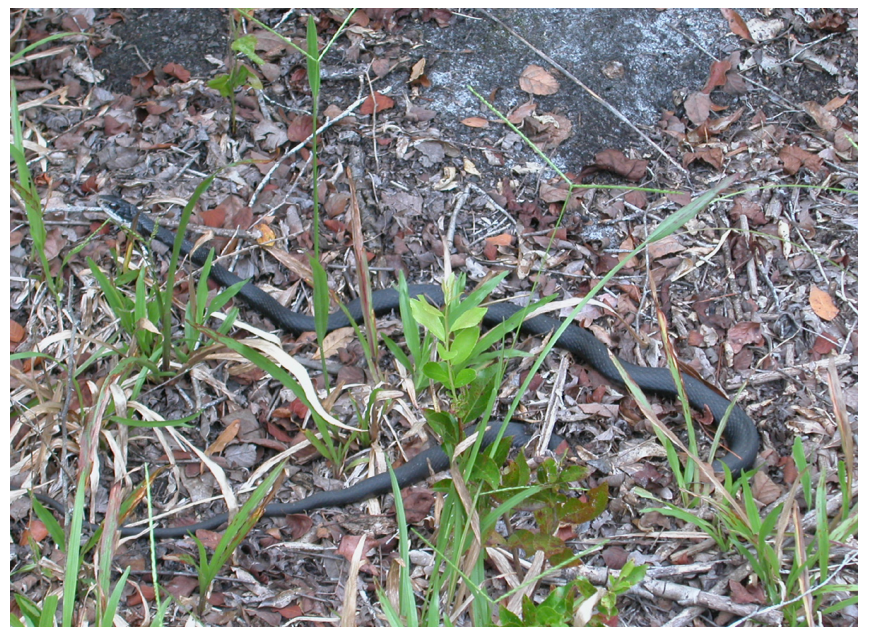

Figure 1. Southern Black Racer (Adult). Credits: Steve A. Johnson, University of Florida

Adult Black Racers are commonly found sunning themselves on lawns, shrubbery, walkways and fences, and are occasionally found in houses (particularly after rains). Racers are harmless to people and are swift and agile (as their name implies), fleeing rapidly when approached. However, if they are cornered and feel threatened, they may vigorously shake their tail (making a rattling sound on the floor or dry leaves) and may release a foul smelling 'musk' on their captor or even strike if handled. Black Racers use their speed to catch a variety of prey, including frogs, lizards, small snakes, birds, and rodents.

Due to their dark coloration, harmless Black Racers are sometimes incorrectly identified as venomous Cottonmouth Water Moccasins (Figure 16), which have rather thick, heavy bodies with rough-looking keeled scales (with longitudinal ridges) and blocky heads. Young Black Racers (Figure 2) are also long and slender, but bear little resemblance to adults. They have a series of reddish-brown blotches down the middle of their backs on a gray background and abundant small, dark specks on their sides and bellies.

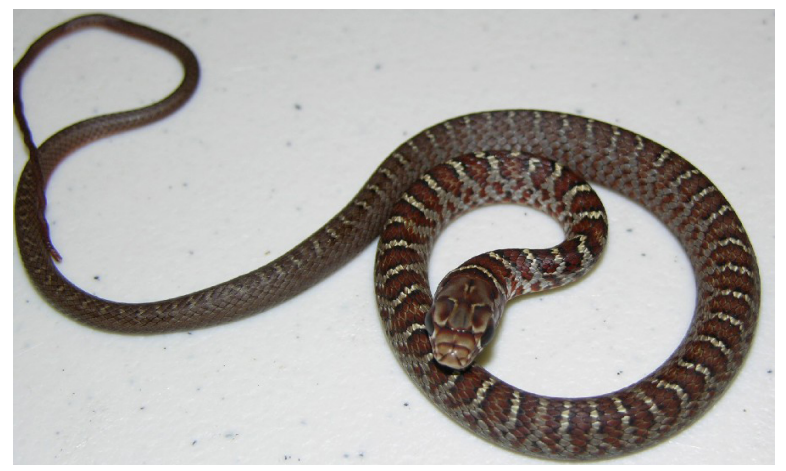

Figure 2. Southern Black Racer (Juvenile) - note the slender body and reddish colored blotches. Credits: Steve A. Johnson, University of Florida

There are several other "Black Snakes" found throughout the southeastern U.S. that are often difficult to identify. Of these, only the Black Racer and Southern Ring-necked Snake (also described here) are commonly found in residential areas. Additional information about "Black Snakes" and tips on identification can be found in the document "Black Snakes": Identification and Ecology, available online through the University of Florida's Electronic Data Information Source (EDIS) at http://edis.ifas.ufl.edu/UW251.

\section{"Flower Pot Snake" - Brahminy Blind Snake}

\section{Brahminy Blind Snakes (Ramphotyphlops} braminus) are tiny (2-6 inches), brownish-black, earthworm-like snakes with nearly invisible eyes and no distinct head or tail (Figure 3).

Unlike earthworms, these non-native snakes are smooth and are not segmented. They were introduced to Florida through the ornamental plant trade (hence the name "Flower Pot Snake") and are one of the most commonly found snakes in urban areas throughout peninsular Florida. Notably, the prevalence of this non-native species can be attributed in part to the fact that all Brahminy Blind Snakes are female, meaning that a single individual can reproduce asexually by a process called 'parthenogenesis'. These tiny snakes burrow in potted plants or flower beds, feeding on larval ants and 


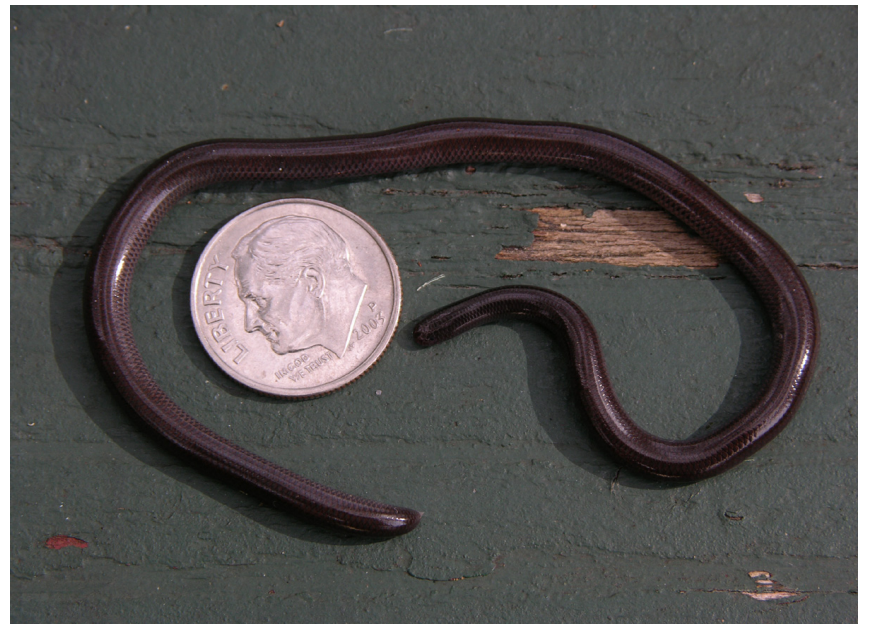

Figure 3. "Flower Pot Snake" or Brahminy Blind Snake, shown next to a dime for size comparison (Adult). Credits: Jason Butler, 2007

termites, and are occasionally found in houses, as their small size allows them to slip in under doors. These snakes are completely harmless to humans, and may be removed from the house by sweeping them into a bucket or small garbage can.

\section{Southern Ring-necked Snake}

\section{Southern Ring-necked Snakes (Diadophis} punctatus) are one of the most commonly found snake species in urban areas throughout all of Florida, where they are found in leaf litter or mulch, on walkways, and sometimes in houses. They occasionally fall into pools and end up in the skimmer basket. These small, grayish-black snakes rarely grow longer than 12 inches, and can be easily identified by the obvious ring of orange or yellow around the neck and a matching brightly colored belly with a row of black spots down the center (Figures 4 \& 5). When alarmed or threatened, Ring-necked Snakes coil their tail like a corkscrew and may emit a foul scent, although they rarely attempt to bite.

These shy snakes are harmless, preferring to spend their time under logs and rocks, where they eat earthworms, slugs, salamanders, lizards, and small snakes. Due to their small size, these snakes may be unable to climb out of pools and may inadvertently slip into a house under doors. They can easily be removed from the pool using a leaf skimmer or from the house by sweeping them into a bucket or small garbage can. Release them in nearby shrubs, so that

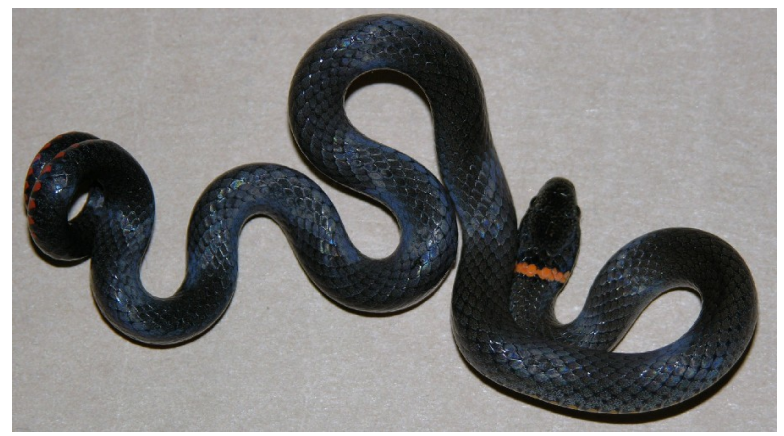

Figure 4. A Southern Ring-necked Snake (Adult) showing typical defensive posture-note the coiled tail. Credits: Steve A. Johnson, University of Florida

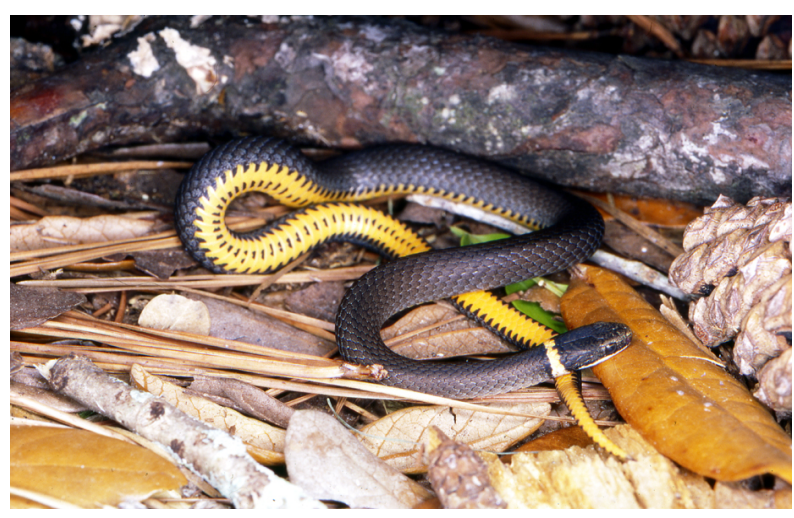

Figure 5. Southern Ring-necked Snake (Adult) showing yellow belly coloration. Credits: Kenneth Krysko, FLMNH, University of Florida, 1996

these harmless snakes can continue to eat your garden slugs!

\section{Rat Snakes}

Red Rat Snakes, also known as Corn Snakes (Elaphe guttata, Figure 6) are frequently found in urban areas throughout Florida. These beautiful snakes have reddish-orange blotches (outlined in black) on their backs and sides on a highly variable background of tan, gray, or yellow-orange, and a distinctive black and white "checkerboard" pattern on their bellies.

Due to their reddish coloration, these snakes are occasionally confused with coral snakes (Figure 17). However, non-venomous Red Rat Snakes are generally larger (3-5 feet), and lack the distinct black nose and red, yellow and black bands of coral snakes.

\section{Yellow Rat Snakes (Elaphe obsoleta, Figure 7)} are closely related to Red Rat Snakes, and are frequently found in urban areas throughout peninsular Florida (not found in the Panhandle). This is a large 


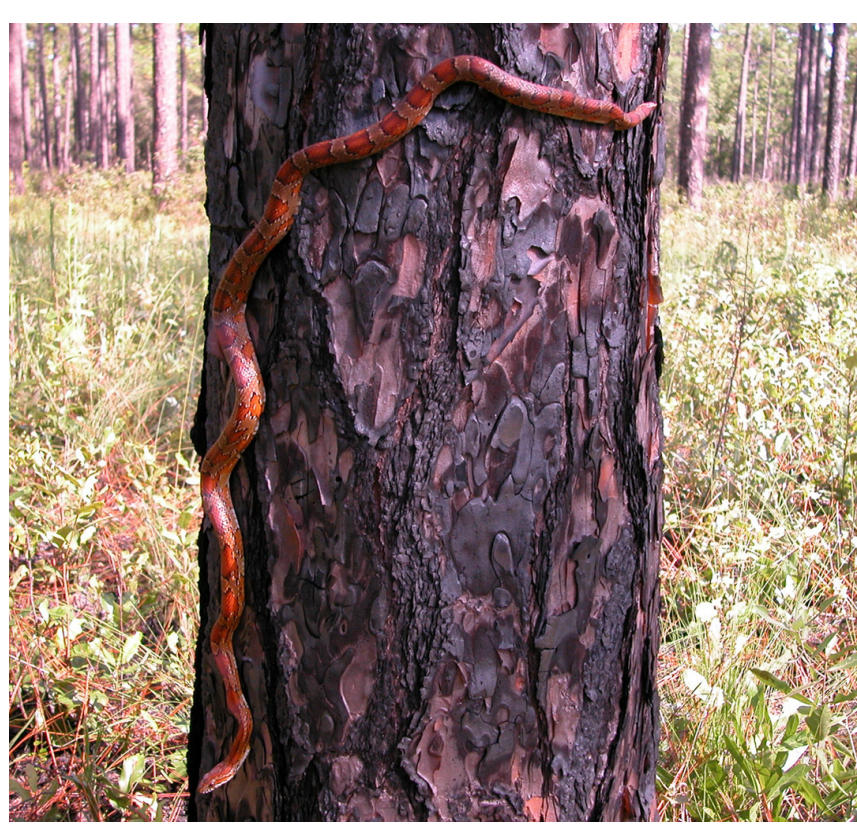

Figure 6. Red Rat Snake (Adult), demonstrating its superior climbing skills. Credits: Steve A. Johnson, University of Florida

(4-6 feet), distinctive golden yellow snake with four dark longitudinal lines running down its back.

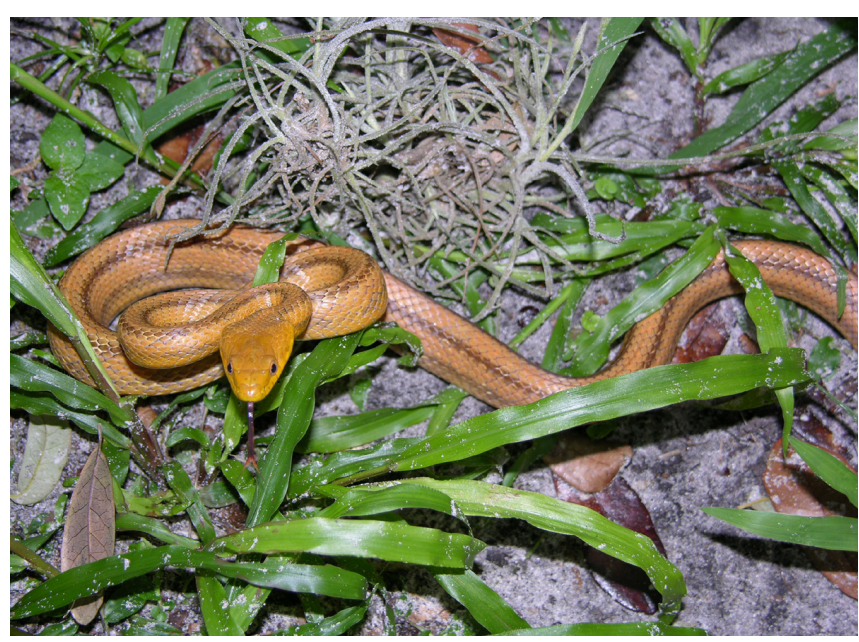

Figure 7. Yellow Rat Snake (Adult). Credits: Steve A. Johnson, University of Florida, 2004

Juvenile Red Rat and Yellow Rat Snakes look similar and resemble Red Rat Snake adults, albeit a dull, brownish version. As Yellow Rat Snakes grow, the blotches will fuse to form the longitudinal lines seen in adults, and the gray-brown background coloration turns to yellow-orange. Typical juvenile rat snake markings are shown in Figure 8 below.

Both Yellow and Red Rat Snakes are excellent climbers and are frequently found in residential areas on shrubs or fences. They are also found on occasion

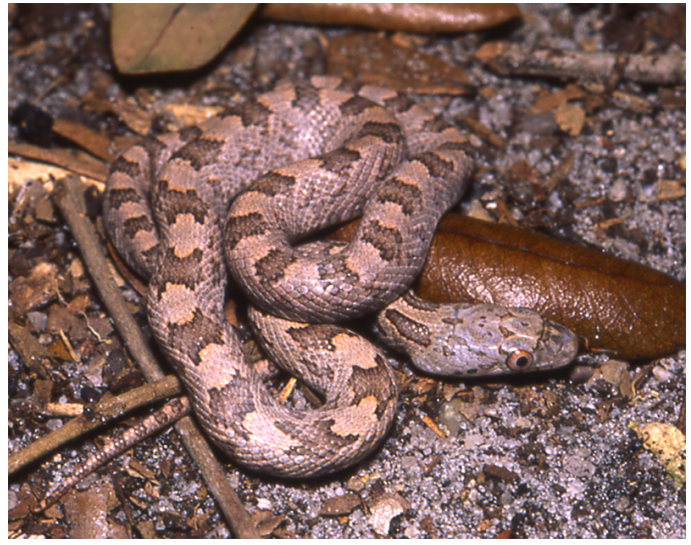

Figure 8. Juvenile Yellow Rat Snake - Markings are typical of juvenile rat snakes. Credits: Kenneth Krysko, FLMNH, University of Florida

in garages and even in bathrooms inside the home, where they gain entrance by way of holes in walls or uncovered roof vent-pipes. These are harmless non-venomous snakes, but can be quite defensive and may emit a foul smelling musk and strike when cornered. If found in the house, you may be able to remove these snakes by using a broom to gently guide them into a large outdoor garbage can, which can then be covered and used to relocate the snake outdoors. In the garage, you may be able to gently guide the snake through an open door using a broom. If this is not possible, remember that Rat Snakes feed primarily on rodents - after they rid you of your rodent pests, they will likely move on in search of food and water. In addition, there are many preventative methods, detailed in the next document of this series, which will greatly reduce your chances of an indoor encounter with a snake.

\section{Garter Snakes}

Eastern Garter Snakes (Thamnophis sirtalis, Figure 9) are frequently encountered in urban areas throughout Florida. Eastern Garter Snakes are small-medium sized snakes (2-3 feet long) with keeled scales marked with three light-colored longitudinal lines, one down the middle of the back and one along each side of the body. There is also a "checkerboard" pattern of black splotches down the back between the stripes.

Due to this splotched pattern, Eastern Garter Snakes are occasionally misidentified as Pygmy Rattlesnakes (Figure 15), which have large, irregular blotches, much thicker bodies, blocky heads, vertical 


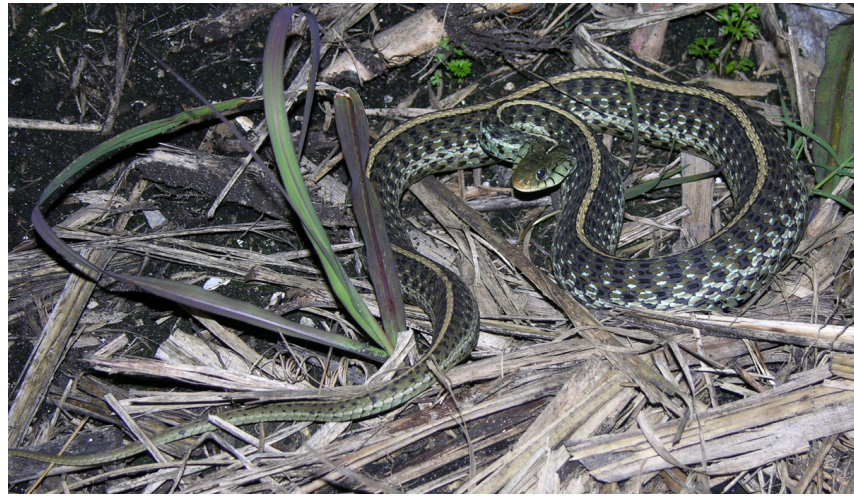

Figure 9. Eastern Garter Snake (Adult). Credits: Steve A. Johnson, University of Florida

pupils, and a dark stripe through the eye to the corner of the jaw.

Eastern Garter Snakes feed primarily on small prey such as earthworms, frogs, and salamanders. In urban areas, they are often found among shrubbery near houses, along the edges of ditches or ponds, and may even get into bathrooms inside a home, gaining entrance by way of holes in walls. These snakes are generally docile, but when cornered may release a foul smelling musk and flatten their heads and bodies to appear more imposing. These harmless snakes may be removed from the house by sweeping them into a bucket or small garbage can. Preventive methods, detailed in the next document in this series, can help to eliminate unwanted indoor encounters with snakes.

\section{Rough Green Snake}

The Rough Green Snake (Opheodrys aestivus) was once among the most commonly encountered snakes in Florida, and may still be encountered in urban settings. This small, slender snake grows to only 2-3 feet in length, and can be easily recognized by its bright green, keeled scales, which give it a rough appearance (Figure 10). The belly is generally a cream or pale yellow color.

This snake is often seen sunning itself on bushes or in trees but is seldom (if ever) encountered in houses. These snakes are docile, and will generally attempt to stay still, relying on their green camouflage to keep them hidden when approached by people. If camouflage does not work they will quickly flee through the branches of shrubs and small trees. Rough Green Snakes specialize in eating insects they

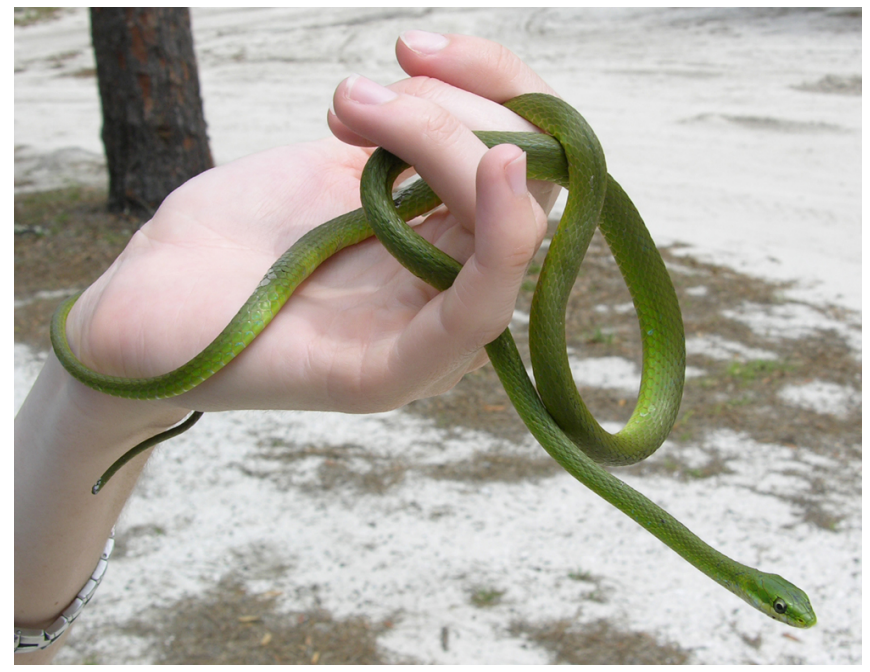

Figure 10. Rough Green Snake (Adult). Credits: Steve A. Johnson, University of Florida

find on bushes or trees, and should be left in place to play their role in the environment.

\section{Southern "Banded" Water Snakes}

Southern Water Snakes (Nerodia fasciata), are perhaps the most commonly misidentified non-venomous snake species-people often confuse them with the venomous Cottonmouth. Southern Water Snakes have rough-looking, keeled scales, and can reach up to 5 feet in length (typical size ranges from 2-4 feet). The Banded Water Snake (N. f. fasciata) has dark crossbands on a lighter colored background (Figure 11).

The crossbands are quite variable in color, and may be black, brown, or even red. The background color of these snakes may be brown, gray, dull yellow, or reddish brown.

The closely related Florida Banded Water Snake (N.f. pictiventris) has similar crossband markings, and a distinctly marked belly. The Latin name "pictiventris" means "painted belly" and refers to the conspicuous dark markings on the belly of these snakes (Figure 12).

In both subspecies the crossbands tend to darken as the snakes age, and large snakes may be a nearly uniform dark-color (Figure 13).

These large, dark-colored snakes also have dark "eye stripes" through the eye to the corner of the jaw, and large individuals are easily (and frequently) 


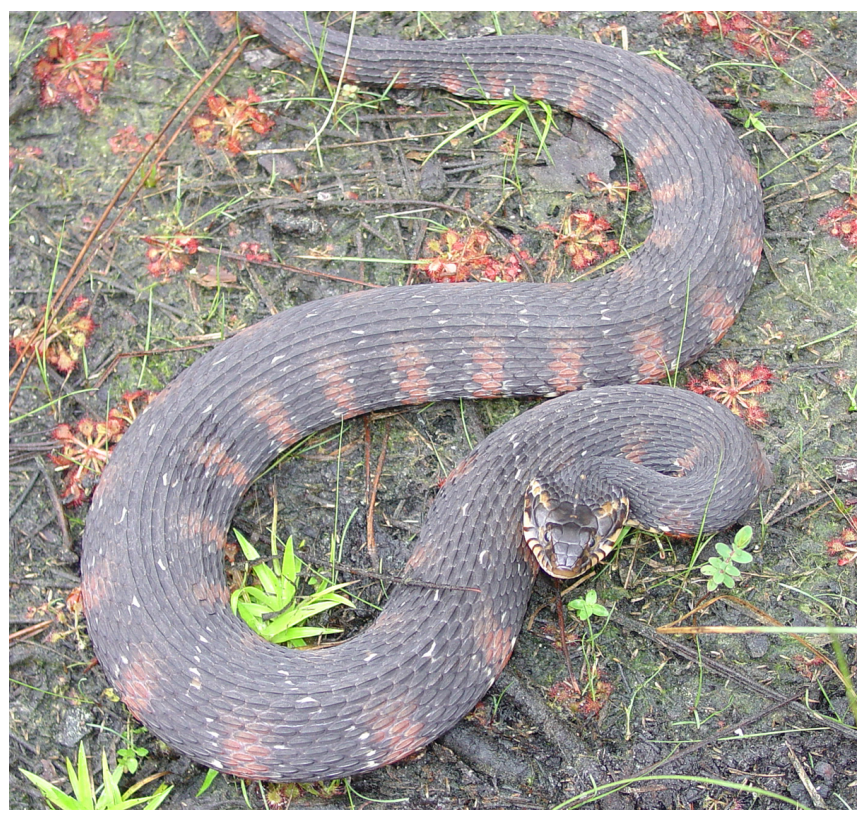

Figure 11. Banded Water Snake (Adult) showing typical banded pattern. This snake feels threatened and has flattened its head and puffed up its body to look more intimidating. Credits: Kenneth Krysko, FLMNH, University of Florida

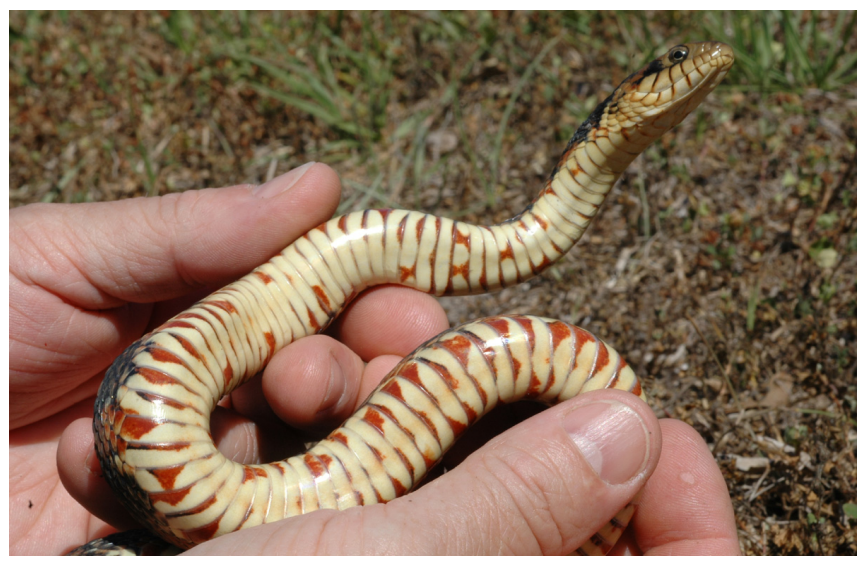

Figure 12. Florida Banded Water Snake (Adult), showing markings on belly scales. Credits: Photo courtesy of USGS

confused with the venomous Cottonmouth Water Moccasin (Figure 16). When threatened, water snakes will flatten their heads and bodies in an attempt to look larger and more intimidating. These snakes prey upon salamanders, frogs, fish and crayfish, and are often encountered along the edges of ditches and ponds, in the same habitats where Cottonmouths are found. If you encounter a large, dark snake that you cannot confidently identify, particularly near water, "leave it be!" Even the non-venomous water snakes should not be handled unless absolutely necessary, as they release an especially foul-smelling musk and sometimes bite

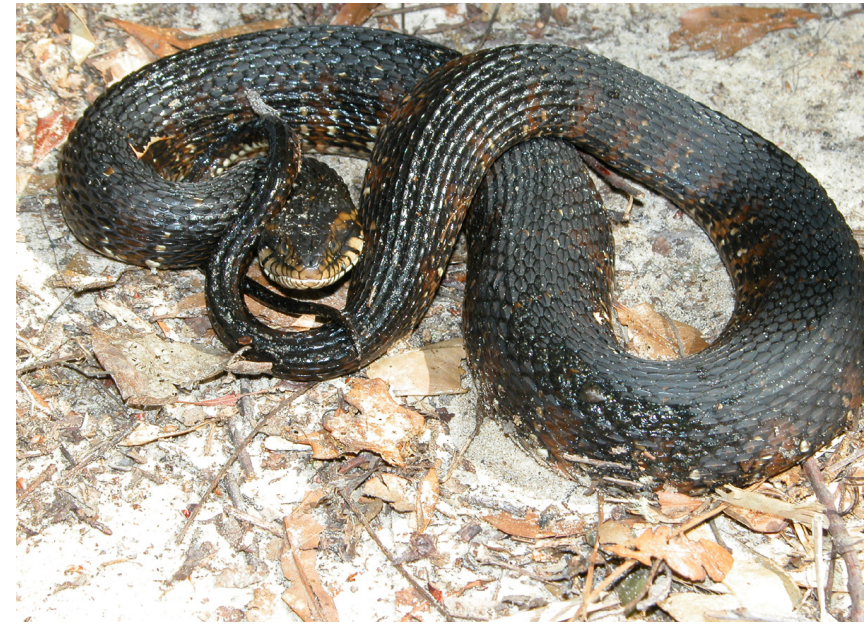

Figure 13. Banded Water Snake (not a Cottonmouth), showing nearly uniform dark coloration. This snake feels threatened and has flattened its head and puffed up its body to look more intimidating. Credits: Photo courtesy of USGS

when they feel threatened. If necessary, these snakes can be relocated using a broom to guide them into a large garbage can - although they will likely attempt to escape to the safety of any nearby water.

\section{FLORIDA'S VENOMOUS SNAKES}

Of the approximately twenty species of venomous snakes found in the United States, only six are found in Florida, and only four are found in central and southern Florida. Florida's venomous snakes belong to two families - the Viperidae or "Pit Vipers" (5 species) and the Elapidae, represented in Florida by the Coral Snake. The four species described here are the most commonly encountered venomous snakes in Florida. More information on identifying all six of Florida's venomous snake species can be found in "Recognizing Florida's Venomous Snakes", an educational document available online through the University of Florida's Electronic Data Information Source (EDIS) at http://edis.ifas.ufl.edu/UW229.

Learning to identify Florida's most commonly encountered venomous snakes is essential, not only for safety reasons but also to alleviate the fears that lead to needless persecution of snakes. As you learn more about snakes and begin to understand them, you will see that all snakes - even venomous species are beneficial and play important roles in our environment. Negative encounters with venomous 
snakes are rare and several precautions, described in the next document in this series, will help prevent such unwanted encounters in residential areas.

\section{PIT VIPERS - VIPERIDAE}

The pit vipers found in Florida all share certain characteristics that can help you to learn to identify them. They all have bodies that are rather thick and heavy for their length, heat sensing pits on the side of the face, vertical pupils, and they usually have a dark stripe through the eye to the corner of the jaw (as do some non-venomous water snakes). Pit vipers also have rough-looking, keeled scales (with longitudinal ridges) and wide, somewhat triangular heads with obvious thin necks. However, many non-venomous species also have keeled scales and triangular heads, and should not be mistaken for venomous snakes. If you arent sure, be safe - give the snake its space!

\section{Eastern Diamondback Rattlesnake}

The Eastern Diamondback Rattlesnake (Crotalus adamanteus, Figure 14) is Florida's largest venomous snake, typically ranging in size from 3-6 feet (record length 8 feet!), and is found throughout the state of Florida. This snake can easily be identified by the large black diamonds with beige borders, which are repeated down the back.

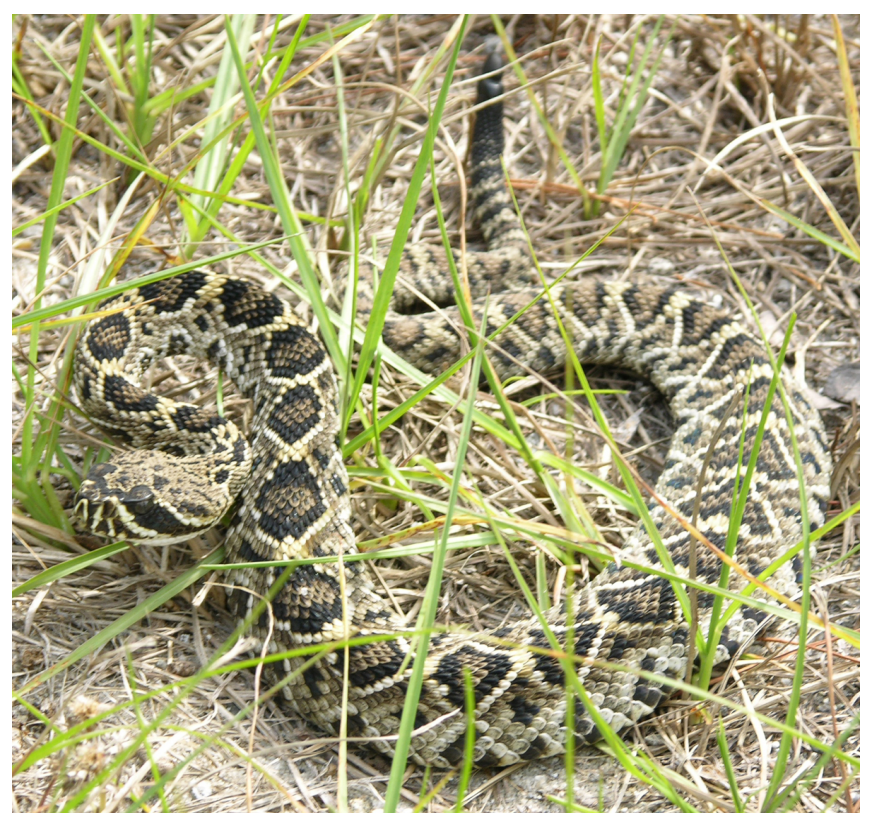

Figure 14. Eastern Diamondback Rattlesnake (Adult). Credits: Steve A. Johnson, University of Florida
These snakes have large, blocky heads with a distinctive dark band from the eye to the corner of the jaw, rough-looking keeled scales, and may have large rattles at the tip of the tail that usually make a loud buzzing sound when the snake feels threatened. Juvenile Eastern Diamondback Rattlesnakes are similar in appearance to adults, and can also be easily identified.

The Eastern Diamondback Rattlesnake is rarely found in urban areas, preferring more natural scrub or wooded areas, where it preys on mice, rats, and rabbits. However, they occasionally wander onto golf courses and into suburban neighborhoods that are near pine forests. Eastern Diamondback Rattlesnakes have declined severely in numbers due to habitat loss, road mortality, and indiscriminate killing by people. The Eastern Diamondback Rattlesnake should be respected and admired from a safe distance. It can strike up to two-thirds its body length and possesses the largest quantity of the most toxic venom (at least to mice) of any species in the United States. If you encounter this snake, "leave it be" -- DO NOT attempt to approach, handle or kill it!

\section{Pygmy Rattlesnake}

The Pygmy Rattlesnake (Sistrurus miliarius, Figure 15) is the smallest venomous snake in Florida, averaging one foot in length, and feeds primarily on frogs, toads, and mice. Found throughout the state, this is the most commonly encountered venomous snake in Florida, and can be found in a variety of urban settings.

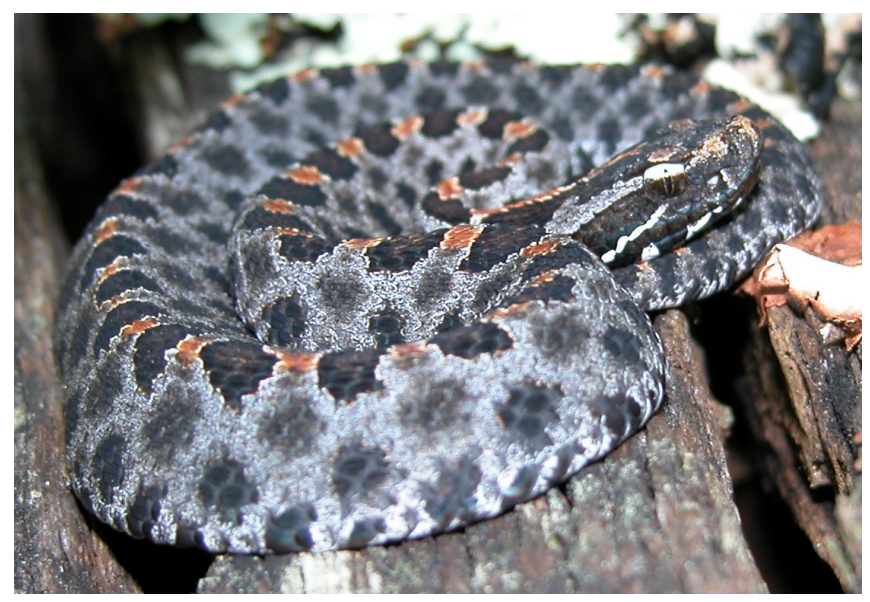

Figure 15. Pygmy Rattlesnake (Adult). Credits: Steve A. Johnson, University of Florida 
Although small, the Pygmy Rattlesnake has a stout body and blocky head. The body is gray with irregular dark blotches down the back and sides and a broken reddish-brown line down the center of the back between blotches. There is also a distinctive dark line through the eye to the corner of the jaw. Juveniles are similar in appearance, but the tip of the tail is a bright yellowish color.

Although Pygmy Rattlesnakes do have a rattle, it is so small it is barely audible and makes an insect-like buzzing noise. These small rattlesnakes are quite defensive - if approached, they may hold their ground and strike at their perceived attacker. It is a good idea to wear leather gloves at all times while gardening, as these venomous snakes are often encountered in flower beds and gardens.

\section{Cottonmouth}

The Cottonmouth (Agkistrodon piscivorus, Figure 16), also known as the Water Moccasin, is the most aquatic venomous snake in Florida. It is occasionally seen in urban areas throughout Florida near the edges of ditches, ponds, lakes, and wetlands, where it feeds on fishes, frogs, mice, and rats.

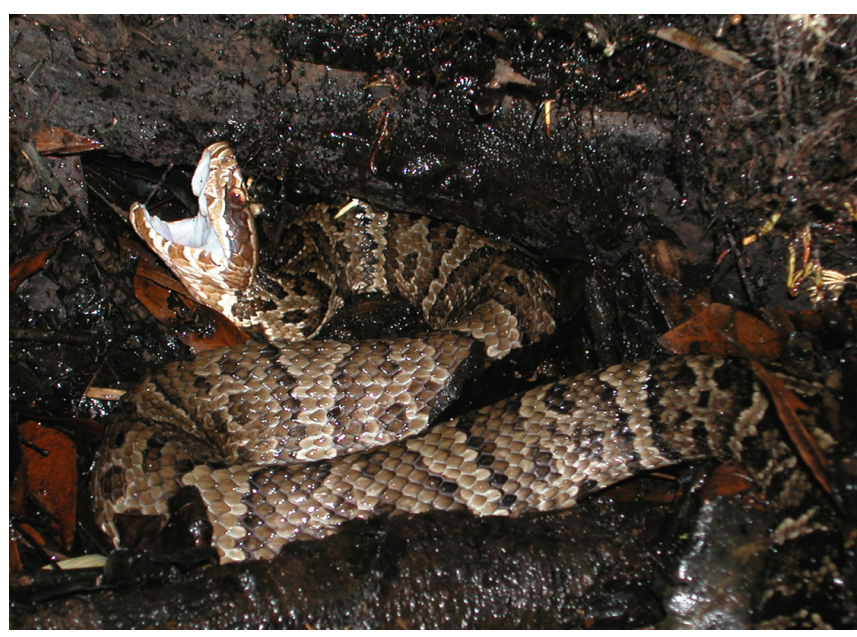

Figure 16. Cottonmouth (Adult), showing banded markings and the namesake defensive posture. Credits: Steve A. Johnson, University of Florida

These heavy-bodied snakes can grow to 6 feet in length (typical size ranges from 2-4 feet), and have rough-looking, keeled scales. Young Cottonmouths resemble the closely related Copperhead, and have bright reddish-brown, splotched crossbands, a dark stripe through the eye to the corner of the jaw, and a bright yellow-tipped tail. The crossbands darken with age, and older snakes may be nearly uniformly dark-colored.

As mentioned in the previous section, several species of non-venomous water snakes are often misidentified as Cottonmouths. In order to avoid being bitten, it is best to never attempt to handle any aquatic snake. Cottonmouths do not have rattles, but may vigorously shake their tail when threatened (like many non-venomous snakes), making a rattling sound in dry leaves. As a defensive behavior, Cottonmouths may coil their body and open their mouth widely, showing the namesake cotton-white interior. These behaviors are defensive, rather than aggressive, and, despite their infamous reputation as being aggressive, Cottonmouths will generally flee from threat unless harassed.

\section{CORALSNAKES - ELAPIDAE}

\section{Harlequin Coral Snake}

The Harlequin Coral Snake (Micrurus fulvius, Figure 17), is a small (1 - 2.5 feet in length), slender, secretive snake that spends most of its life underground. This snake feeds on lizards and other snakes. Coral Snakes occur in residential areas, where they may be encountered under brush piles, firewood, or other objects under which they hide. You may also encounter a Coral Snake while you are digging in your yard to plant shrubs or a garden. Coral Snakes stay in hiding most of the time, and if you see one in the open it will likely be moving rapidly across your lawn to a new hiding place.

Coral Snakes have smooth, glossy scales and are brightly colored with red, yellow, and black rings. Their snout is blunt and black, followed by a band of yellow, and their body is marked with wide red and black rings separated by narrow yellow rings (the colored rings go all the way around the snake), and the tail is black and yellow.

There are two non-venomous Coral Snake "look-alikes" (Scarlet Kingsnake and Scarlet Snake) that can be confused with the Coral Snake at first glance, but they can easily be identified as non-venomous by the order of their colored bands (red touching black). Remember the "stoplight 


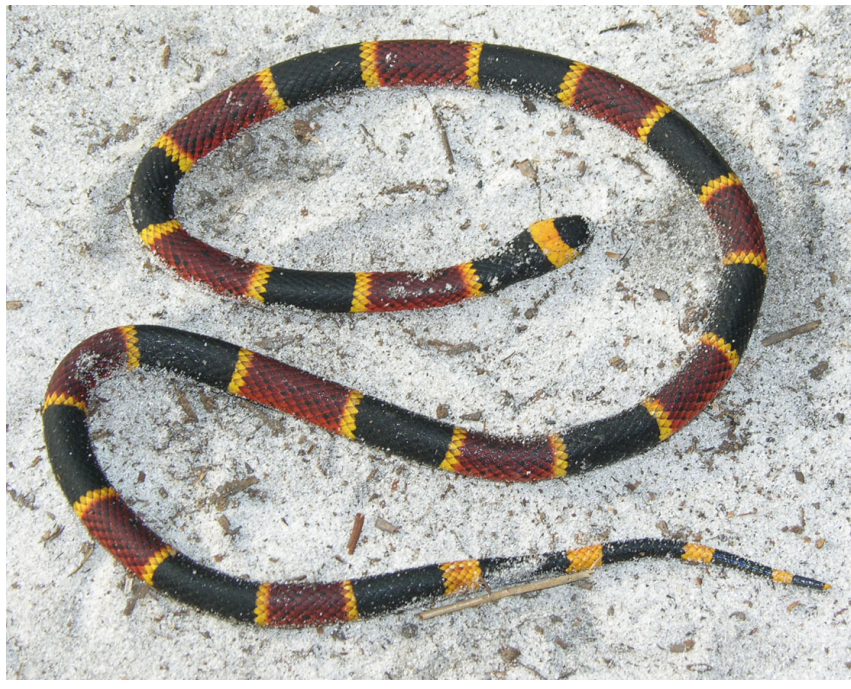

Figure 17. Harlequin Coralsnake (Adult) - Note the black nose and the touching red and yellow bands. Credits: Steve A. Johnson, University of Florida

phrase" -- when you see a snake with bright red, yellow \& black bands, remember "yellow, red, STOP!" In the venomous Coral Snake, the yellow and red bands touch. In the two non-venomous species the black and red bands touch - these snakes also have red, rather than black, snouts.

Interestingly, all of the pit vipers give birth to live young, and the Harlequin Coral Snake is the only venomous egg-laying species in Florida. Therefore, when snake eggs are encountered, they almost certainly belong to a non-venomous species and can be left in place unharmed without fear for your safety.

\section{ADDITIONAL RESOURCES}

This document is the second in a series of four documents by Dr. Steve Johnson and Monica McGarrity that provide information to Florida's residents on how to identify snakes that are commonly encountered in residential settings, how to prevent encounters from occurring in the first place, and how to respond in the unlikely event that someone is bitten by a snake. Anyone living in Florida, especially people new to the state, will find these documents useful. These documents are available online through UF/IFAS Extension Electronic Data Information Source.

1. Dealing With Snakes in Florida's Residential Areas - Introduction (http://edis.ifas.ufl.edu/UW257)
2. Dealing With Snakes in Florida's Residential Areas - Identifying Commonly Encountered Snakes (http://edis.ifas.ufl.edu/UW258)

3. Dealing With Snakes in Florida's Residential Areas - Preventing Encounters (http://edis.ifas.ufl.edu/UW260)

4. Dealing With Snakes in Florida's Residential Areas - Emergency Planning (http://edis.ifas.ufl.edu/UW261)

\section{Hotline Numbers:}

Poison Control Hotline: 1-800-222-1222

American Society for the Prevention of Cruelty to Animals (ASPCA) Poisoning Hotline:

1-888-426-4435 (charges may apply)

\section{Good Books on Florida Snakes:}

Conant, R., and J. Collins. 1998. Peterson Field Guide to Reptiles and Amphibians of Eastern and Central North America, 3rd edition. Boston: Houghton Mifflin Company.

Carmichael, P., and W. Williams. 2004. Florida's Fabulous Reptiles and Amphibians. Tampa: World Publications.

Tennant, A. 2003. Snakes of North America: Eastern and Central Regions. revised edition. Houston: Lone Star Books.

\section{Snake Resources on the World Wide Web:}

Johnson, S.A. 2005. Dealing with Venomous

\section{Snakes in Florida Schoolyards Series.}

WEC199-202. Gainesville: Institute of Food and Agricultural Services.

http://edis.ifas.ufl.edu/

TOPIC_SERIES_Dealing_with_Venomous_Snakes_i n_Florida_School_Yards

Johnson, S.A., and M.E. McGarrity. "Black

Snakes": Identification and Ecology. WEC214.

Gainesville: Institute of Food and Agricultural

Services. 2006. http://edis.ifas.ufl.edu/UW251 
Florida Museum of Natural History-Online guide

to Florida snakes:

http://www.flmnh.ufl.edu/herpetology/FLGUIDE/

onlineguide.htm

\section{Florida Fish and Wildlife Conservation}

Commission snake

page:http://www.myfwc.com/critters/snakes.asp

\section{Partners in Amphibians and Reptile}

\section{Conservation (PARC) site:}

http://www.parcplace.org/index.html

\section{Snake Handling Equipment:}

Midwest Tongs - http://www.tongs.com (we

recommend their Gentle Giant tongs)

Tomahawk Live Trap -

http://www.tomahawklivetrap.com (we recommend their 60" Super Tube tongs with rubber cushions) 